\author{
EVS27 Symposium \\ Barcelona, Spain, November 17-20, 2013
}

An overview of electric and solar boats market in France

Bernard GUELLARD - President of The French Electric Boats Association

Xavier de MONTGROS - Director ODC Marine

Philippe PALLU DE LA BARRIERE - CEO ALT.EN SA,

GuY WOLFENSBERGER - Director GROVES BOATS SA

Philippe D'OLIVEIRA - Sales \& Technical Manager SODETREL

Paper number 9160691

\begin{abstract}
Electric boats (EBoats) ${ }^{1}$ have a major role to play for the transportation of passengers, and even goods, into the centre of the cities endowed with seaborne or fluvial paths or in each places to fit the environmental rules decided by local authorities to limit the access to protected water areas. Waterways accessing downtown are identified in many cities as relevant commuting solutions. Three market segments are emerging based on the boat uses: spare-time activities, public transportation services and goods or services applications. These boats have been developed for inland as well as maritime waters: they exist in pure electrical or hybrid versions depending on needs. They use lead acid, NiCad or lithium batteries technology.

The French Electric Boats Association (AFBE), including 60 members, has identified to key levers for the development of this market: strengthening the industry position and boosting the governmental incentives.

This document offers a description of the most significant electric boats applications in France, while providing the technical key points that allowed such efficient services to be reached.
\end{abstract}

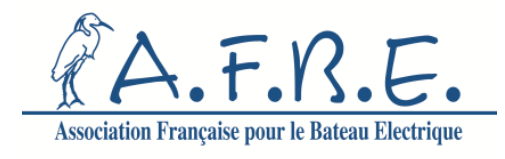

${ }^{1}$ In this paper, Eboats means mainly boat using battery as energy storage

EVS27 International Battery, Hybrid and Fuel Cell Electric Vehicle Symposium 


\section{An overview of electric and solar boats market in France}

Eboats have a major role to play for the transportation of passengers, and even goods into the center of the cities that are lucky enough to possess a water way as river or seaside. Also Eboats provide interesting solutions for spare time activities.

The key point to develop this market is mainly depending of technical solutions (energy storage and efficiency of propulsion systems, aluminum or composite material...) which are now available. The demand for Eboat solutions is increasing because of electric transportation is an answer to environmental and health concerns.

\section{1 - Introduction}

The first electric boat, named Eureka, using lead acid batteries was built in 1881 by the French chemist engineer Gustave Trouvé and it was the beginning of the Eboat story. But the limited range due to lack of energy available on board was a brake on the development. However lead acid or nickel cadmium batteries have proved their efficiency for a lot of boats which are always used today.

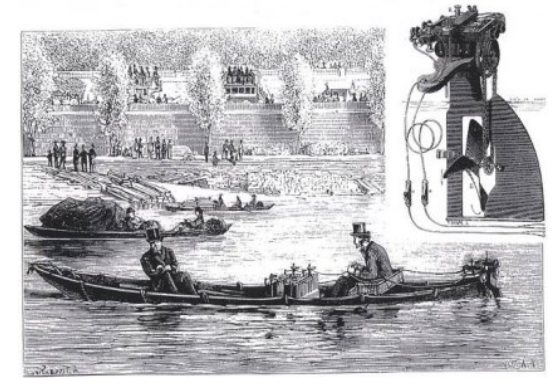

Figure 1 - Eureka on the river Seine in 1881

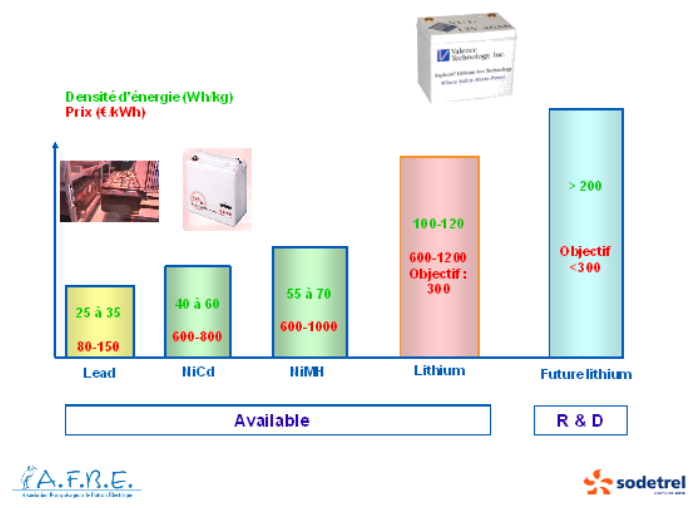

Figure 2 - Batteries technologies
Since 1881, the storage electricity technology is the focus of R\&D and up to now some lithium solution seems to be a good way to achieve an interesting daily range, including a safe battery management system.

Other solutions as hybrid system, fuel cells or super capacitors are tested and should be promising opportunities.

On board solar panels provide an extra energy source increasing autonomy.

In the same time the interest for the sustainable development constraints in the transportation field gives an increasing interest to the Eboats clean solutions: no polluting emission, silent and high torque at low speed pitch.

But it's important to note that an Eboat could not be an adaptation of a regular thermic one due to the need of high energy efficiency.

Low energy consumption is required but it's necessary to assure an acceptable commercial speed.

The design of hull and superstructure weight must be adapted to electric boat.

In 2012, the AFBE staff decided to present an electric boat definition. The main criteria is the time during the boat is fully propelled by the on board battery and electricity must be identify as unique source of energy. This time was fixed to $50 \%$ of the daily exploitation range. 


\section{2 - The Eboats market}

Three main market segments are identified into a study launched by AFBE in 2010: sparetime activities (short time rental boat, fishing applications...), urban shuttle public transports and good transportation and services.

Indeed many cities have waterways that go right to the center or to commute between home and office and are therefore ideal for the transport of persons as they avoid the main roads and traffic jams.

There are already many electric boats being used for such local transport, but there are new offers coming to the market for new boats, specially designed to be optimized in terms of energy usage and convenience.

However it is certainly in this domain of public transport with boats from 50 to 200 seats that the technique has advanced most rapidly. It is possible to have performances that allow such services to be met easily and efficiently.

Many projects are studied with naval architect offices to respond to demand from local authorities and private companies oriented to provide clean and sustainable solutions to transport people. During the last 12 months more than 2000000 persons have been transported in France with Boat's !

\section{3 - An overview of French applications}

\section{1 - Hybrid passenger boats}

ODC Marine has started delivering full electric passenger passengers boats in 2009 using the latest and powerful Lithium batteries technologies. Some full electric passenger boats can go up to $80 \%$ of hull speed which means 8 to 12 Knots max and 5 to 7 Knots cruising. Full electric is a great choice when boat programs can accept an autonomy of $4^{\wedge} \mathrm{h}$ at these cruising speed.

In a few cases although it is great to be in full electric mode when leaving the harbor, visiting a natural parc or entering a protected area, but at the same time the boat needs to go from point $A$ to point $B$ at higher speed such as 20 Knots. To be able to cruise at 20 knots, those boat need to sail at planning speed thus they need 10 times more energy: this is the reason why ODC Marine developed hybrid technologies enabling full speed at unlimited autonomy and offering the quietness and cleanliness of full electric where it is wished.

ODC Marine hybrid boats have been in commercial service with 100 passengers on board since early 2009 . Such boats are powered by $2 \mathrm{x} 400 \mathrm{HP}$ in diesel and $2 \mathrm{x} 100 \mathrm{HP}$ when electric. Boats can be charged onshore, preferred and also while sailing. Lithium batteries will do at least as good linked to number of cycle proven, LiFePO4, first passenger boat in operation was designed and produced by ODC Marine in 2009 and is still in operation with 100\% original cells .

We can develop in more details of different hybrid technologies that ODC Marine has experimented parallel or serial, for different usages in complement to fill electric solutions. 

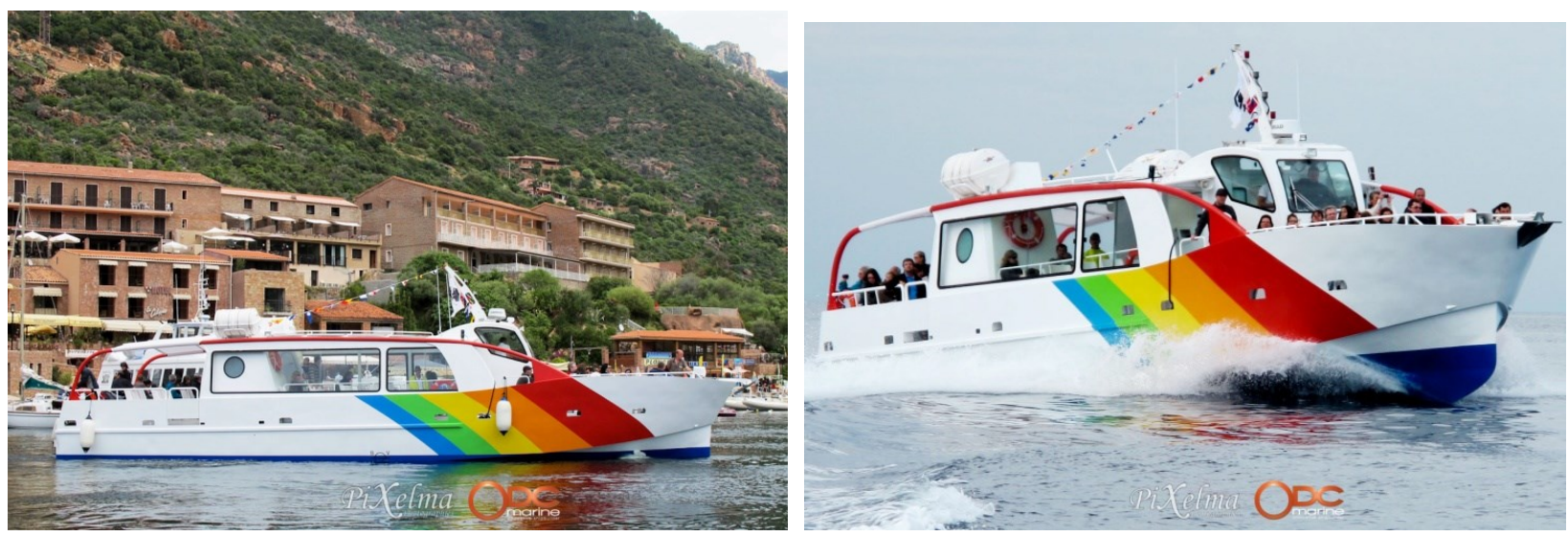

Figure 3 - ODC boat operating in Corsica

\section{2 - Zero Emission Electric Ships in France}

A Zero Emission Electric Ship (ZES) is defined as a ship which doesn't use any fossil fuel when operating. Since the end of nineties, this kind of boat has been remarkably developing in France. In fact two kind of application have been specially emerging:

- passengers transportation of medium size (30 PAX to 80 PAX) specially for shuttles

- leisure boat of small size (3-4 PAX) specially for rental.

They are also few small supply harbor boats for transportation or cleaning.

As technical and economical frames are not the same for medium size passengers boats and small size leisure boats, we deal only with ZES passengers ship.

They are about thirty passengers ZES operating in France until now:

\begin{tabular}{|c|c|c|c|c|}
\hline ShipYard & $\begin{array}{c}\text { Amount of ships } \\
\text { operating }\end{array}$ & $\begin{array}{c}\text { Totalized } \\
\text { passengers capacity }\end{array}$ & $\begin{array}{l}\text { Location of } \\
\text { operation }\end{array}$ & Application \\
\hline Alt.En & 12 & 700 PAX & $\begin{array}{l}\text { Paris } \\
\text { La Rochelle } \\
\text { Marseille } \\
\text { Les Sables d'Olonne } \\
\text { Cognac }\end{array}$ & Shuttles \\
\hline Chantier Franco-Suisse & 4 & 250 PAX & Doubs & Tourism \\
\hline ODC Marine & 6 & 475 PAX & $\begin{array}{l}\text { Paris, Lac Léman } \\
\text { South France, } \\
\text { Corsica, Electric } \\
\text { \&Hybrid }\end{array}$ & $\begin{array}{l}\text { Tourism } \\
\text { Shuttle }\end{array}$ \\
\hline GROVES Boats & 2 & $120 \mathrm{PAX}$ & Annecy & $\begin{array}{c}\text { Shuttle } \\
\text { Tourism }\end{array}$ \\
\hline GenHy & 3 & 80 PAX & $\begin{array}{l}\text { Monaco } \\
\text { Port Camargue }\end{array}$ & $\begin{array}{l}\text { Shuttle } \\
\text { Shuttles }\end{array}$ \\
\hline Aluminox & 1 & $50 \mathrm{PAX}$ & Nevers & Tourism \\
\hline Aquawatt & 1 & 60 PAX & Lot & Tourism \\
\hline
\end{tabular}

A boat without emission for at least $50 \%$ of his travel time is defined as electric boat by AFBE. (ZES).From 1990 many of those boats have been set to operation in France. They are used for :

- Permanent transport line ( from 30 to 100 Passengers)

- Leasure boats for 3 to 15 people 
- Utility boats such as harbour cleaning

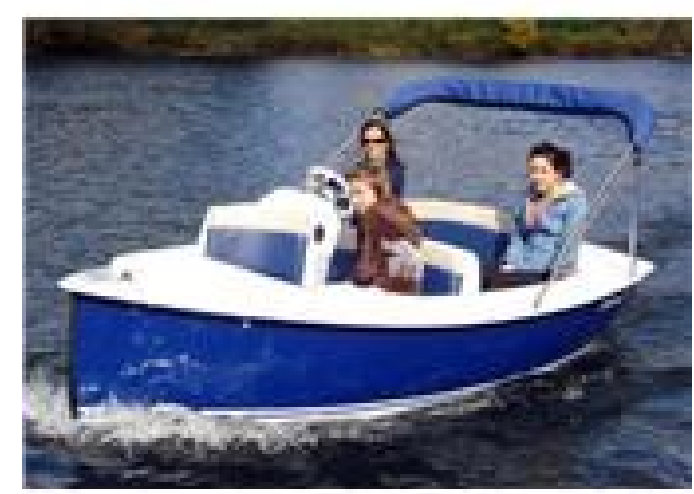

Figure 4 - ACE from Ruban Bleu

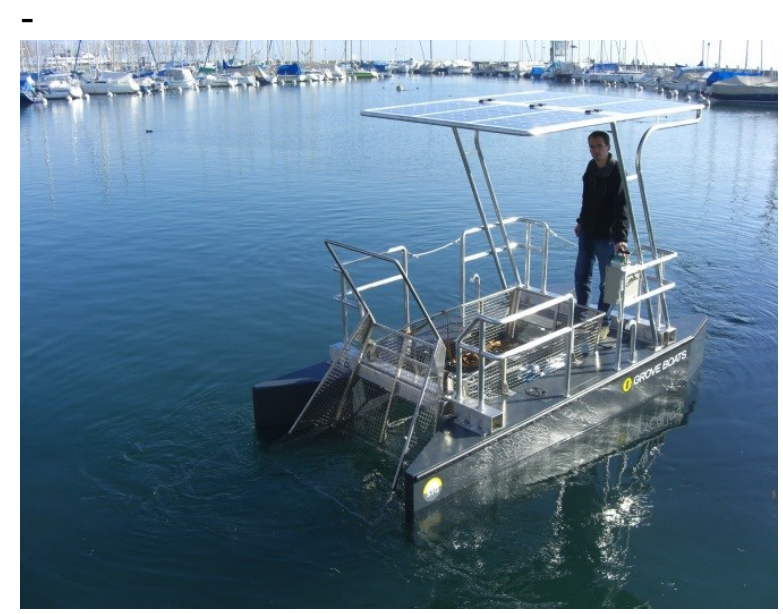

Figure 5 -Solar sea cleaner - Grove Boats

For spare-time activities or pleasure markets the most common propulsion methods are based on lead acid batteries and, with speeds of up to $15 \mathrm{~km} / \mathrm{h}$ it is possible to have an adequate operating range. These electric boats used for fishing or row are mainly rented for few hours based on the on board storage electricity capacity available. Up to now, in France this market is around 300 boats per year and the French boat maker company Ruban Bleu is leader but other small companies are emerging on this segment. There are some 3500 electric boats sizing from 4 to 12 persons used in France.

They are also few "twin energies" passengers ships able to operate alternatively ZE and ICE by using generator (Bordeaux, Lorient).
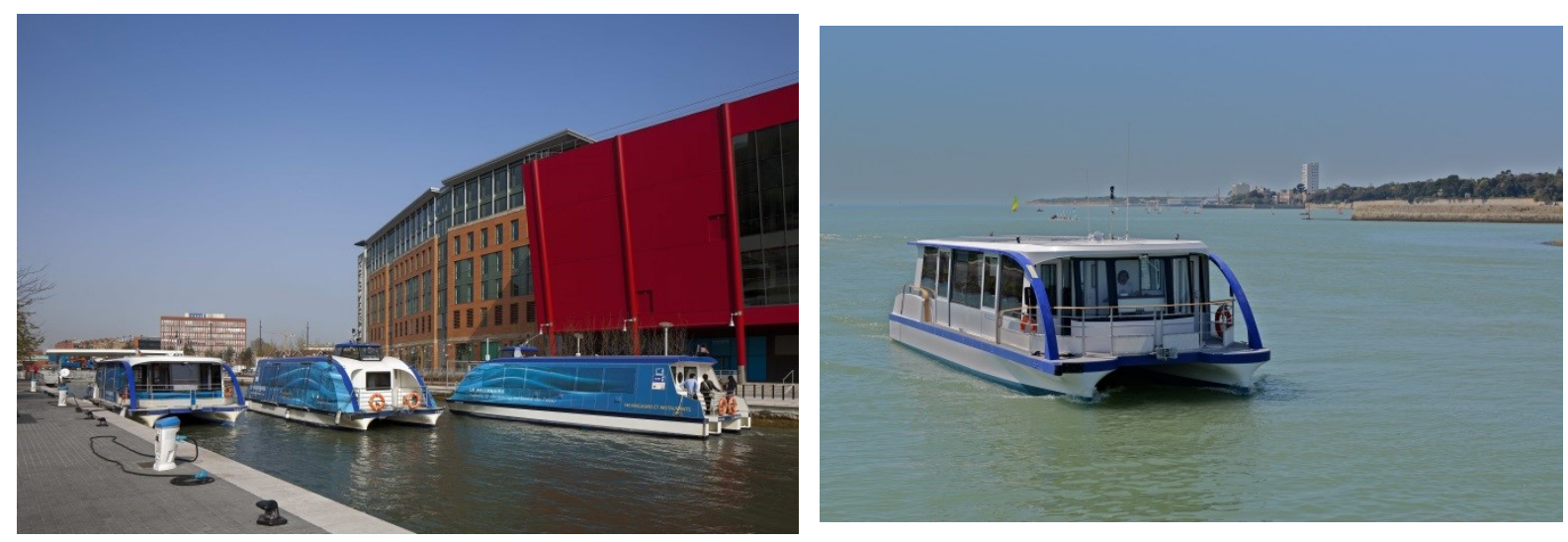

Figure 6 - Two AltEn ZES in Paris and La Rochelle

The main two issues for passengers ZES are:

- Satisfy the required operations conditions.

Operator generally specifies an operating speed and a daily schedule. Consumption per distance of ship propulsion increase more and more quickly with speed when the amount of stored energy is limited by weight (nor really by room).

Shuttle operating require a high level of availability of ship which require a perfect reliability of the storage energy system including charge.

- Cost-effectiveness for operator:

ZES ship, even not including in the cost the energy storage system, is more expansive than conventional boat especially when boat is optimized for heavy service. Cost-effectiveness 
requires balancing the over cost of boa t\& energy storage system by saving fuel and reducing maintenance.

\section{Technical solutions}

In case of tourism applications, boats operate at speed not exceeding $8 \mathrm{~km} / \mathrm{h}$ during only few hours each day. As a result, basic technology using steel conventional boat, high rpm inboard propulsion and lead batteries allow reaching the service.

Shuttle service is more stringent solutions are required (operating speed of at least $12 \mathrm{~km} / \mathrm{h}$ and 8 to 12 hours every day or $6 \mathrm{~km} / \mathrm{h}$ for whole photovoltaic boats). As a result, more performing and efficient solutions are needed for all boat components.

\section{Ship : reduction of hydrodynamic resistance}

- Weight reduction by using composite material or aluminum alloy and weight saving on equipment and accommodations. The boat has to be built in the same spirit than high speed ferry boat. For example a ZES 80 PAX built by ALT.EN weight about 11 tons in light condition without battery when conventional passenger boat of the same capacity weights about 18 tons.

- Optimization of the hull shape: for example catamaran allows combining large deck area for passengers and reduced wetted area.

- Optimization of waterline length regarding operating speed. Drag of hull increase quickly up to a critical speed which increase with waterline length. For example, for catamaran:

\begin{tabular}{|l|l|l|l|}
\hline Critical speed $\mathrm{km} / \mathrm{h}$ & $7 \mathrm{~km} / \mathrm{h}$ & $12 \mathrm{~km} / \mathrm{h}$ & $18 \mathrm{~km} / \mathrm{h}$ \\
\hline Waterline lengtth m & $10 \mathrm{~m}$ & $15 \mathrm{~m}$ & $18 \mathrm{~m}$ \\
\hline
\end{tabular}

\section{Propulsion : improve electric, hydrodynamic and mechanical efficiency}

- Permanent magnet synchronous engine optimized for operating rpm

- Propeller optimized for operating speed: Optimized propellers for medium operating speed of $12 \mathrm{~km} / \mathrm{h}$ is larger than conventional propeller and rpm is lower (300 to $500 \mathrm{rpm})$. This requires more engine torque or greater gear ratio. In case of inboard engine with shaft, propeller requires more room under hull.

- POD: immersed electric propulsion inside torpedo shape. This solution allows fitting optimized propeller.

Moreover POD can be lifted and rotated which improves maneuvering and maintenance. Cooling system for engine is avoided. Every ALT.EN ships are propelled by PODs.

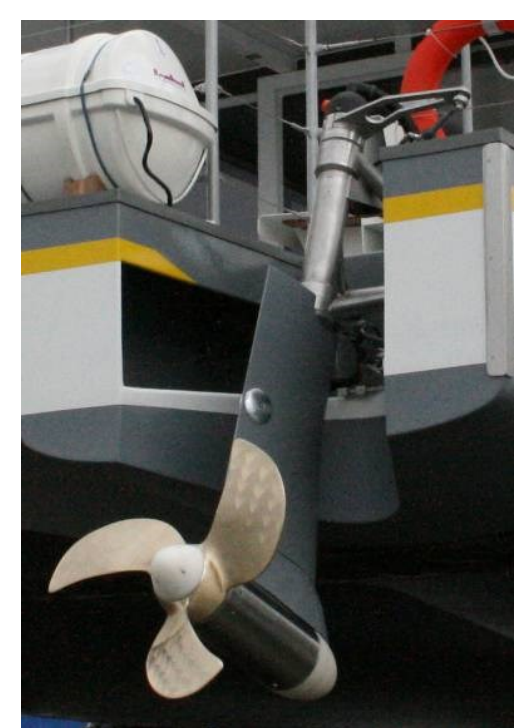

Figure 7 - ALT.EN POD

For optimized ship and propulsion the power maxi of propulsion becomes:

\begin{tabular}{|l|l|l|l|}
\hline Operating speed km/h & $7 \mathrm{~km} / \mathrm{h}$ & $12 \mathrm{~km} / \mathrm{h}$ & $18 \mathrm{~km} / \mathrm{h}$ \\
\hline Power max engines & $20 \mathrm{kWh}$ & $40 \mathrm{kWh}$ & $100 \mathrm{kWh}$ \\
\hline
\end{tabular}


Only half of power is used at operating speed. Operating power of conventional heavy boat is often more than twice.

\section{Photovoltaic production : a significant contribution}

The roof of the ship allows installing significant photovoltaic power (4 $\mathrm{kWc}$ for an $80 \mathrm{PAX})$. Contribution of photovoltaic in \% depends obviously of the operating speed:

\begin{tabular}{|l|l|l|l|}
\hline Operating speed km/h & $7 \mathrm{~km} / \mathrm{h}$ & $12 \mathrm{~km} / \mathrm{h}$ & $18 \mathrm{~km} / \mathrm{h}$ \\
\hline Contribution maxi PV & $100 \%$ & $30 \%$ & $5 \%$ \\
\hline
\end{tabular}

\section{Energy storage system}

Until now, existing French ZES use battery as energy storage. The needed batteries capacity for a whole day of operation is typically:

\begin{tabular}{|l|l|l|l|}
\hline Operating speed $\mathrm{km} / \mathrm{h}$ & $7 \mathrm{~km} / \mathrm{h}$ & $12 \mathrm{~km} / \mathrm{h}$ & $18 \mathrm{~km} / \mathrm{h}$ \\
\hline Batteries capacity & $30-60 \mathrm{kWh}$ & $100-150 \mathrm{kWh}$ & $300-400 \mathrm{kWh}$ \\
\hline
\end{tabular}

Power calls remain quite low regarding battery capacity. As a result, "energy" batteries are used for ZES. After having used lead and NiCd batteries in the first time, LiFePO4 batteries are now extensively used. Weight and volume of such batteries would allow installing 300$400 \mathrm{kWh}$ in $18 \mathrm{~m}$ ship. For the required capacity, high tension of $300 \mathrm{Vto} 700 \mathrm{~V}$ DC is used in order to avoid managing many parallel paths.

Generally, batteries are charged during night using inboard chargers of $15-30 \mathrm{kWh}$ power.

Depending of the service (frequency of stop), it could be profitable to charge at moderate power during calls. For example, ALT.EN has developed an automate to charge by induction during call. This system (patented) has been working for 15 years on two shuttles.

Experience feed -back showed that the lifetime of NiCd batteries used for 4000 hours /years of operation could be more than six years. One expects to reach at least the same lifetime with $\mathrm{LiFePO} 4$ batteries.

Some other energy storage systems are under development or even in test:

Super-capacity: tested on a new shuttle 100PAX built by STX. SuperCap of 30kWh store the energy needed for one rotation (30') and they are charged in 3' during call. The weight is close from the weight of a Lithium pack allowing the whole day autonomy. The high power charging systems need high power electric supply ashore. STX expect to reach consequent increase of lifetime comparing to batteries.

Hydrogen: The specific energy of Hydrogen-PAC system is potentially twice of the lithium FePO4 storage system. The needed room is greater but not critical for this kind of boat. Hydrogen system could allow increasing autonomy without overweight. The German boat ZEMSHIP operating to Hamburg is the more experienced hydrogen passenger boat. Some projects are under development in France. The main issues are safety, rules, H2 storage, lifetime of membrane and supply on board of hydrogen.

\section{Performances and limitations}


Speed and autonomy, has seen before, operating speed of passengers ZES has to be moderate. In case where the boat has to operate more than about 8 hours per day, the operating speed is limited at $12-15 \mathrm{~km} / \mathrm{h}$ for a $15 \mathrm{~m}$ ship. To note that the allowable operating speed increase with the water length of ship.

Maneuverability is really improved by the lightening of ship and by reactivity of electric drive. Crew enjoys the behavior of those ships. Moreover, rotating PODS make the docking easier and faster.

ZES ships are more than a little less noisy than ICE ships: $60 \mathrm{db}$ inside ALT;EN passenger's cabin composite ship using POD's comparing to more than $80 \mathrm{db}$ for ICE metallic ships.

Heating and air conditioned: As the consumption of such devices could be greater than propulsion, they have to be avoided or optimized: cabin isolation, natural aeration using the closeness of fresh water, heat pump.

\section{Experience, reliability, maintenance}

The French fleet of passengers ZES totalizes about one hundred years of operation. The first boats have been operating since 15 years. The more used ALT.EN ships (4000 hours / year) reach a ratio of $98 \%$ of successful service which prove that high quality components allow to operate a ZES ship like anybody else regular public transport vehicle.

To get such results, it has founded of strategic importance to always use components in the range of here specifications. ALT.EN and his partner's EVE have developed a powerful supervision system which allows to supervise and manage the main electric components using several sensors connected to a dedicated computer UCVE by CAN network. UCVE show parameters (warning, alarms...) to the crew but also send data in real time to an external server. That allows the ALT.EN team to manage the system during operation if necessary.

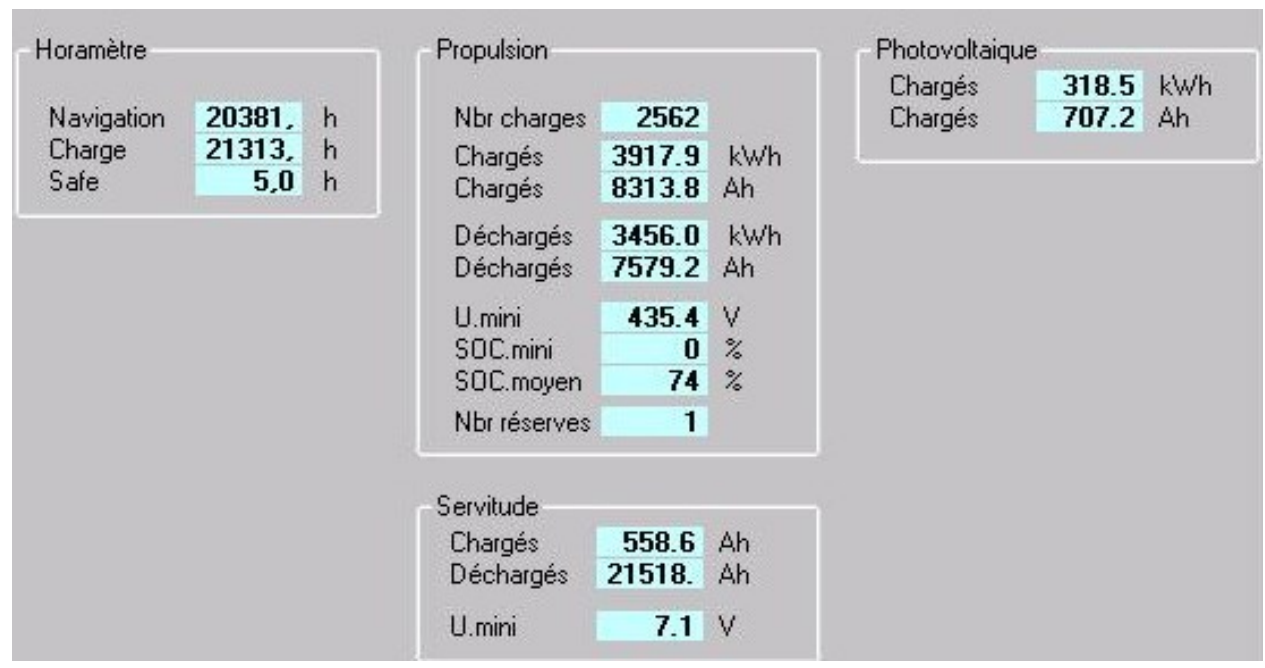

\section{Economic aspects:}

Not as cars or buses, ZES ships are not granted in France until now.

Economic performance of passengers ZES comparing to conventional ICE ships depends of four main parameters:

- $\quad$ operating time / year of the ship

- $\quad$ cost of batteries (or energy storage system)

- $\quad$ cost of fossil fuel 
- $\quad$ cost of electric energy

Modern batteries reach a lifetime of 6 years for operating time of 4000 hours/years. However, for operating time of 1000 hours/years, lifetime of batteries don't increase so much.

The analyze of respective investment and operating costs on the basis of French prices for electricity, fuel, batteries shows that:

- $\quad$ Cost of electric charge is not significant (only few euros / day)

- $\quad$ Based on operating time of $4000 \mathrm{~h} / \mathrm{y}$, the cost of saved fuel greatly exceeds the cost of batteries. This profit, combined with maintenance saving costs allow to pay the over cost of an optimized ZES in 10 years.

- $\quad$ Based on operating time of $1000 \mathrm{~h} / \mathrm{y}$, cost of saved fuel and batteries are very close.

Considering decreasing battery cost and increasing fuel cost, we can expect that economic competitiveness of ZES will improve continuously, which will allow to extend the range of application of such boats.

\section{3 - Solar powered boats: the beginnings}

While electric powered crafts have been experimented since the 1830's (and amongst pioneers, Sir Grove was the first to introduce fuel cells as a source of energy on-board of a boat), the first documented solar powered boat has been the "Solar Craft 1" built by the Alan T.Freeman and that made its maiden voyage on $19^{\text {th }}$ February 1975.

The first crafts consisted of simple photovoltaic panels set up on canoes, harnessing the power of the sun to propel the long and thin hulls that mankind has developed along the last millenniums as the most efficient boat hull shapes.
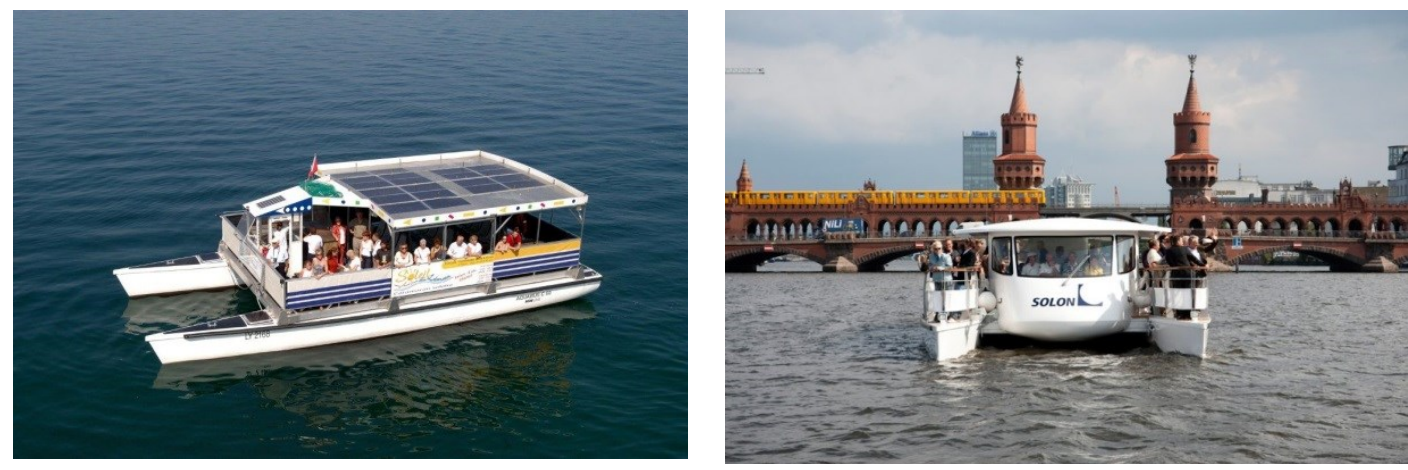

Figure 8 - Two Grove Boats in Evian and Berlin

In the nineties, some pioneers further developed the technology, enabling the first boats to enter " commercial» service, mainly around inland waterways (see the "Solifleur" in use in the lake Neuchatel as early as 1994. Built by the Swiss company MW-Line it had been financed by the nature friendly "Yves Rocher» cosmetics company and still run today throughout a nature reserve).

That decade saw quite a number of solar boats races organized throughout Europe, popularizing the concept and further developing the techniques (some boats reached top speed over $25 \mathrm{~km} / \mathrm{h}$ ). The Friesian solar challenge remains as of the today a widely sought after competition (unofficially called «the World Cup for Solar Powered Boats »!), bringing together engineering schools, passionate boats builder and even some technology company. 
Improved battery storage and performances of the photovoltaic panels opened the ways to " world premières »: the Channel was first crossed in 1997 ("SB Collinda), the Pacific in 1996 ("Malt's mermaid"), the Atlantic in 2007 (the Swiss craft "Sun21" left Basel to reach New York) and lastly, another Swiss vessel, Planet Solar" reached Monaco in May 2012 as the first boat to ever circumnavigate the Globe using solar power only!

These developments proved that solar powered boats can do very well; the downside of their relative lower speed being very much offset by their comfort of navigation, zero emission, milder wave making and last but not least low operating costs.

\section{Recent developments in the fields of solar powered water crafts}

Two main factors encouraged the current growth of solar powered boats: technology and popularity, setting up the foundations for an emerging commercial market.

\section{Technological improvements:}

- Energy storage: helped by recent developments notably in portable electronics (laptops, phones) and then the automotive industry, new types of batteries appeared along the well-known and proven lead-batteries: Nickel-Cadmium, Lithium-Polymers ... While some of these new products still face some issues (high costs, security, lack of recyclable circuits...), they very clearly opened the door for extended autonomy, lower weight, faster recharging time as well as longer life-cycles.

- Improved performances of the photovoltaic panels: improvement in both the production techniques as well as the implementation of solar-tracking mechanisms resulted in a drastic increased efficiency of the newer generation of PV panels (cells performances of $22 \%$, enabling an overall $18 \%$ performance per panels are now largely the norm). Furthermore, the mass-production (solar powered boats used industrial standards, i.e. identical to the ones that one can install on a roof or a PVSolar farm) enabled a steep price decrease, that translate today to a cost close to 1 EUR / Watt

- Hybrid systems: after the somehow natural move to enable the batteries to be recharged from the grid as for any "pure electric boat», new sources of energy appeared as a complement to the solar power: diesel operated in-board generators or even fuel-cell (see Hamburg, WHY super yacht). On top of the improved batteries, these systems functions as range-extender, sometime necessary to overcome the relatively limited autonomy. These hybrid systems start to blur the difference between a « pure solar » and a « pure electric » boat...

\section{Popularity}

Quite a few factors explain a shift toward a better understanding and a stronger interest in solar powered boats.

- The automotive industry move towards electric vehicles certainly explains a massive shift towards a better understanding and trust towards electric propulsions.

- Identically, the ever increasing surfaces covered with photovoltaic panels popularized the solar energy as a source of trusted power.

- The increased oil price, global geopolitical context in oil producing countries as well as the recent Fukushima catastrophe definitively encourages a move towards « green and clean » attitude benefiting solar-powered boats.

- Importantly as well, the legislation framework evolved in some areas encouraging the use of less polluting water crafts and thus indirectly encouraging solar-powered boats: partial or total prohibition of combustion engines (see for e.g. in some Austrian Alpine 
lakes), the move away from 4-stroke motors as well as limited speed or engine-power (Swiss lakes for e.g.) or even reserving some harbours slots to electrical engines only (Annecy lake in France is currently introducing such a scheme).

- Last, a significant part of the boat users now demands a more relaxing, softer and cleaner approach to navigation. Solar powered boats, with their pollution free, zero emission, quiet and clean propulsion fulfil these aspirations.

The above factors explain a stronger demand for solar-powered crafts; a commercial market is thus slowly structuring along the following lines:

- Professional transport, focus on tourism: the Swiss based Grove-Boats continues the pioneering work from MW-line and further develops the famous « Aquabus » line (10 to 100 pax)

- Boats for private users: the US-based company produces «the Loon » (winner of the 2010 Mansura Trophy, Inland water) and a French sailor has launched the « Aequus 7.0» to cater for this market

- Experimental projects: quite a few newcomers, amongst them the Australian based «Solar Sailor»

\section{The future...}

The vessel «Planet Solar », successfully demonstrated that a 95 tons « super yacht » can rely endlessly on solar power and thus significantly answered the question of autonomy!

Other super yachts are quietly integrating solar as a partial source of energy; the same goes for commercial crafts, noting that again hybrid is the key word: wind ( "sky sails » and wind turbines), fuel cells and other innovations like the usage of hydro generator are joining forces with the sun to offer a less polluting and more enjoyable way to cruise on the waters of our beautiful planet.

\section{4 - Eboats battery services}

SODETREL actively participates in the development of full electric solutions for buses, delivery trucks, boats (up to 75 pax) and small touristic trains. We provide technical and regulatory expertise to local authorities, companies or

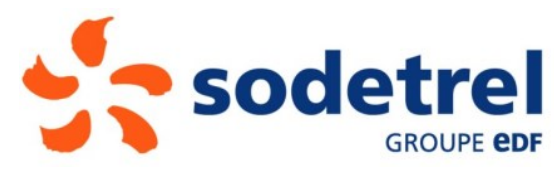
public transport operators wishing to operate "clean" transportation.

SODETREL is actively involved for more than 15 years in the development of "clean" transport with its lease and maintenance contracts for EVs batteries.

SODETREL offers to local authorities and companies its global service called "onboard energy" including :

- Consulting, case study and definition of energy requirements (battery, charging station) ;

- Lease contracts from 3 up to 10 years ;

- Maintenance and good working warranty on the contract length ;

- Management of a spare parts stock in order to minimize the EV immobilization in case of incident ;

- Battery dismantling, transfer to the recycling plant and recycling at the end of life of the battery. 
So far SODETREL operates :

- $\quad 0.5 \mathrm{MWh}$ of Nickel Cadmium batteries (electric Boats and electric train);

- $\quad$ 1.3 MWh of lead batteries (electric buses);

- 4.7 MWh Lithium Ion Battery (electric buses, electric delivery trucks and electric boats).

SODETREL is certified ISO 14001: 2004 by AFNOR for its Environmental Management System.

SODETREL is certified for its activities related to the organization and monitoring of transportation, recycling and preventive maintenance activities of traction lead acid, nickel cadmium, nickel metal hydride and lithium batteries.

SODETREL guarantees a quality and valuable service, respectful of the environment.

\section{4 - The French Electric Boats Association - AFBE.}

The French Electric Boats Association (AFBE) has been created in 1994, currently 60 members. AFBE try to increase the market development with target to participate to install an industrial transfer and to boost the incentives government actions.

The AFBE aims are multiple:

- Promote the conception, construction and use of electric boats;

- Enhance the development of sustainable mobility and preserve the ecosystem and ensure clean fluvial yachting;

- Innovate to develop an eco-boating, information events and studies;

- Act as representative spokesman with governmental authorities

- Unify and federate the players in this sector

To develop this market some concrete actions are engaged and must be encouraged:

1 - Information actions to present the reality of the Eboat industry and experiments;

2 - Definition of technical rules and standardization to organize the use of electricity on board. AFBE is engaged with ISO and AFNOR to prepare these necessary standards.

3 - As for EV development, the Eboat market need help from politicians to promote this offer based on an environmental approach and to suggest some incentives actions.

For any further information: www.bateau-electrique.com

Key words : Eboats - Public transport - Market - Energy efficiency - Incentives - R\&D 


\section{AUTHORS}

\section{Bernard GUELLARD}

President of the French Electric Boats Association - AFBE

Le Colisée - 10 avenue de l'Arche - La Défense - F 92419 Courbevoie Cedex

bg.conseils69@orange.fr - www.bateau-electrique.com

\section{Xavier de MONTGROS}

Directeur

ODC Marine

xavier@odcmarine.com - www.odcmarine.com

\section{Philipe PALLU DE LA BARRIERE}

CEO ALT.EN SA

ALTERNATIVES ENERGIES

ppallu@alternativesenergies.com - www.alternativesenergies.com

\section{Guy WOLFENSBERGER}

Directeur

GROVE BOATS SA

Guy.wolfensberger@grove-boats.com -www.grove-boats.com

\section{Philippe D'OLIVEIRA}

Sales and technical manager

SODETREL

Philippe.d-oliveira@edf - www.sodetrel.fr 